Euro10.3.00.doc

\title{
Will the Emergence of the Euro Affect World Commodity Prices?
}

by

John T. Cuddington and Hong Liang*

Final version (October 3/00)

* We thank Jeff Katzman and Zhongmin Wang for research assistance. This study has been prepared within the UNU/WIDER project on "EMU: Impact on Europe and the World," which is directed by Charles Wyplosz and financially supported by the Yrjö Jahnsson Foundation and by the Ministry for Foreign Affairs of Finland. The views expressed are those of the authors and do not necessarily represent those of the IMF. 


\title{
Will the Emergence of the Euro Affect World Commodity Prices?
}

\begin{abstract}
The emergence of the Euro as a key currency, perhaps eventually rivaling the U.S. dollar in importance, may have important macroeconomic implications for industrial as well as developing economies in the years ahead. This paper focuses on two related questions. First, what effects, if any, will the Euro have on the volatility of world primary commodity prices? Second, why should the impact of the Euro on real commodity prices be of interest to economic analysts and policy makers?

Our econometric analysis provides evidence that episodes of internal stability of exchange rates among the 11 Euro countries during 1957-98 were associated with periods of lower real commodity price volatility. These stabilizing effects are statistically significant for fertilizer, metals and petroleum, and cereals. A reasonable inference, therefore, is that the establishment of the Euro on January 1, 1999 should be expected to contribute to reduced volatility of world commodity prices, other things equal, if the alternative is the higher euro11 volatility in the $1970 \mathrm{~s}$. On the other hand, a move from the relatively stable euro-11 environment of the early 1990s to a single currency (with zero intra-Euro-11 volatility) will have only a modest impact (reducing) commodity price volatility.
\end{abstract}

\section{Key Words:}

Commodity Prices, Volatility, Exchange Rate Regimes, Euro

\section{JEL Classification:}

F33 (International Monetary Arrangements and Institutions) O13 (Agriculture, Natural Resources,..., Other Primary Products) F41 (Open Economy Macroeconomics) 


\section{Overview}

The emergence of the Euro as a key currency, perhaps eventually rivaling the U.S. dollar in importance, may have important macroeconomic implications for industrial as well as developing economies in the years ahead. This paper focuses on two related questions. First, what effects, if any, will the Euro have on the volatility of world primary commodity prices? Second, why should the impact of the Euro on real commodity prices be of interest to economic analysts and policy makers?

The second question is addressed first in order to motivate our subsequent empirical analysis. Section II provides background information on the importance of commodity trade for the EU countries, as well as other country groups. It then reviews earlier work by Cuddington and Liang (1997), who conclude that the choice of exchange regime in the world economy has had an important effect on world commodity price volatility. Section III discusses proxies for exchange rate volatility for the global financial system as a whole and the "Euro-11" countries, respectively. ${ }^{1}$ Section IV provides some graphical evidence on commodity price volatility and exchange rate volatility within the Euro-11 countries and elsewhere. Section V presents a more formal econometric examination of whether currency volatility among the Euro-11 has affected the volatility of world commodity prices. Using data from January 1957 through December 1998, we find evidence that episodes of greater exchange rate stability within the Euro-zone has been associated with lower volatility of world prices for some, but not all, of the primary commodity prices studied. The last section

\footnotetext{
${ }^{1}$ The eleven countries in the European Monetary System that have adopted the Euro are Austria, Belgium, Finland, France, Germany, Ireland, Italy, Luxembourg, Netherlands, Portugal, and Spain.
} 
concludes by making inferences about the likely impact of the emergence of the Euro on world commodity price volatility in the future. It also suggests directions for future research.

\section{Motivation and Background}

Primary commodities still loom large in international trade. According to Marian Radetzki (1990, p. 5):

In 1985, primary commodities as defined here accounted for some 40 percent of overall exports of goods. The importance of commodities in total trade has been declining over time, and that of manufactures has been rising. The share of commodities was 48 percent in 1965 and 46 percent in 1975. Despite the decline, primary commodities are still sufficiently important to have a substantial impact on the world macroeconomy. Changes in the prices of commodities are known to have strong repercussions, for instance on global inflation rates, or on the exchange rates and levels of economic activity of the raw materials exporting countries.

Within this general trend, he identified an important change within the aggregate of primary commodities:

The fuels group has emerged as a dominant component of overall commodity exports. Oil dominates the group. In the 1980s, nine-tenths of the value of fuel exports comprised oil. As a result of the petroleum price increases in the 1970s, the share of this group in primary commodity trade rose from 20 percent in 1965 to 42 percent in 1975 and 47 percent in $1985 \ldots$ With falling petroleum exports and energy prices from the mid-1980s, the share of fuels in total commodity exports and in global trade declined in subsequent years." (p.5)

Using Radetzki's figures, Table 1 calculates the shares of fuel and non-fuel commodities, respectively, in total merchandise exports. The figures show that fuel commodity exports rose from roughly 10 percent of total exports in 1965 to 19 percent in the 1970s and 1980s. In contrast, the share of non-fuel exports has fallen steadily from 38 percent of total goods exports in 1965 to 21 percent in 1985. Radetzki's data only cover the period through 1985. An April 1999 press release by the World Trade Organization (WTO) (www.wto.org; Press/128), however, suggests that the decline in the share of (fuel and non- 
fuel) primary commodities has continued in the 1990s: "Commodity prices fell sharply in 1998, pushing the share of primary products in world exports below 20 per cent in current price terms for the first time in the post-war period." Steep declines in both oil and non-oil primary commodity prices were a major contributing factor: "Oil prices fell by 30 per cent and non-oil commodity prices fell by 20 per cent in 1998, with very different implications for various countries and regions of the world."

Table 1:

The Declining Share of Non-Fuel Commodities in Total Exports of Goods

\begin{tabular}{|lccc|}
\hline 1. Commodity Trade, & 1965 & 1975 & 1985 \\
$\quad$ share of total exports of goods & $48 \%$ & $46 \%$ & $40 \%$ \\
2. Fuel Commodities & $20 \%$ & $42 \%$ & $47 \%$ \\
$\quad \begin{array}{l}\text { 3hare of Commodity trade } \\
\begin{array}{l}\text { Non-Fuel Commodities } \\
\quad \text { share of Commodity trade }\end{array}\end{array}$ & $80 \%$ & $58 \%$ & $53 \%$ \\
$\begin{array}{l}\text { 4. Fuel Commodities } \\
\quad \text { share of total exports of goods (row 1x2) }\end{array}$ & $10 \%$ & $19 \%$ & $19 \%$ \\
$\begin{array}{l}\text { 5. Non-Fuel Commodities } \\
\text { share of total exports of goods (row 1x3) }\end{array}$ & $38 \%$ & $27 \%$ & $21 \%$ \\
\hline
\end{tabular}

Source: Radetzki. 1990. P.5, for rows 1-3. Rows 4-5 are our calculations.

The European Union is a significant net exporter or net importer for a number of primary commodities, as the data by SITC categories in Table 2 shows. ${ }^{2}$ Intra-EU commodity flows are also important, especially for agricultural crops. The WTO Annual Report (1998, Table IV.4) shows that intra-Western European exports of agricultural products are valued at $\$ 177.6$ billion, two and one half times larger than intra-regional flows within other regional areas. Agricultural exports from Latin America to Western Europe and

${ }^{2}$ At the highly aggregated one-digit level, the SITC categories 0-4 include primary commodities, while categories 5-9 are intermediate and final manufactured goods. 
Table 2

Commodity Exports by SITC Classes and Regions

(percent shares of total exports in respective SITC category)

\begin{tabular}{|c|c|c|c|c|c|c|}
\hline \multirow[b]{2}{*}{ SITC Code } & \multirow[b]{2}{*}{ SITC classes } & & \multicolumn{2}{|c|}{$\begin{array}{l}\text { Developed } \\
\text { Economies }\end{array}$} & \multirow[t]{2}{*}{\begin{tabular}{|l|} 
Developing \\
Economies \\
\end{tabular}} & \multirow[t]{2}{*}{$\begin{array}{l}\begin{array}{l}\text { E. Europe and } \\
\text { former USSR }\end{array} \\
\end{array}$} \\
\hline & & Year & EU & Total & & \\
\hline \multicolumn{7}{|c|}{ Origin of exports of major commodity classes } \\
\hline \multirow[t]{2}{*}{$0-9$} & $\begin{array}{l}\text { All Classes } \\
\text { (Primary Commodities; } \\
\text { Intermediate Goods; } \\
\text { Manufactured Goods) }\end{array}$ & $|1990|$ & 43.0 & 71.3 & 23.4 & 5.3 \\
\hline & & 1996 & 39.6 & 67.5 & 28.7 & 3.8 \\
\hline \multirow[t]{2}{*}{$0 \& 1$} & Food and live animals & 1990 & 45.8 & 68.5 & 28.4 & 3.1 \\
\hline & Beverages \& tobacco & 1996 & 43.3 & 66.4 & 30.5 & 3.1 \\
\hline \multirow[t]{2}{*}{$2 \& 4$} & Crude materials, oil & 1990 & 29.0 & 63.2 & 28.9 & 8.0 \\
\hline & \&fats, (fuel excluded) & 1996 & 25.2 & 59.4 & 34.1 & 6.5 \\
\hline \multirow[t]{2}{*}{3} & lubricants, mineral & 1990 & 14.0 & 27.5 & 56.7 & 15.8 \\
\hline & Fuels \& related material & 1996 & 14.9 & 32.5 & 56.6 & 10.9 \\
\hline \multicolumn{7}{|c|}{ Destination of exports of major commodity classes } \\
\hline \multirow[t]{2}{*}{$0-9$} & $\begin{array}{l}\text { All Classes } \\
\text { (Primary Commodities; } \\
\text { Intermediate Goods; } \\
\text { Manufactured Goods) }\end{array}$ & | $1990 \mid$ & 42.5 & 70.4 & 23.4 & 4.3 \\
\hline & & 1996 & 37.0 & 65.5 & 29.0 & 3.8 \\
\hline \multirow[t]{2}{*}{$0 \& 1$} & Food, live animals & 1990 & 48.1 & 71.3 & 22.9 & 5.2 \\
\hline & Beverages \& tobacco & 1996 & 44.0 & 67.1 & 25.4 & 5.7 \\
\hline \multirow[t]{2}{*}{$2 \& 4$} & Crude materials, oil & 1990 & 41.8 & 68.3 & 25.9 & 5.2 \\
\hline & \& fats, (fuel excluded) & | 1996 & 35.9 & 62.0 & 32.1 & 3.8 \\
\hline \multirow[t]{2}{*}{3} & lubricants, mineral & 1990 & 31.9 & 61.5 & 24.2 & 6.8 \\
\hline & Fuels \& related material & 1996 & 31.6 & 62.1 & 25.1 & 5.1 \\
\hline Notes: & \multicolumn{6}{|c|}{$\begin{array}{l}\text { These data are extracted from } 1996 \text { International Trade Statistics Yearbook, } \\
\text { volume 2, Special Table D: "Structure of world exports by commodity classes } \\
\text { and by regions". The original table has disaggregated regional data for all } \\
\text { SITC categories at the } 1 \text { digit level, in the periods } 1990 \text { and 1993-96. }\end{array}$} \\
\hline
\end{tabular}


from North America to Western Europe were also substantial: $\$ 22.5$ billion and $\$ 17.8$ billion, respectively, in 1997. Much of European agricultural trade has been governed by the Common Agricultural Policy (CAP) since the early 1960s. By 1984, the CAP accounted for over 70 percent of EC spending (Dinan, 1994, p.329). This suggests that changes in commodity price behavior could have potentially large fiscal transfer consequences for Euro11 countries.

Many developing countries still rely heavily on the primary commodity exports. Table 3 shows, by region, countries that rely on the earnings of one primary commodity for more than 50 percent, 20-49 percent, and 10-19 percent, respectively, of their total export earnings. As the list indicates, most commodity dependent exporters are developing, rather than industrialized, countries. 


\section{Table 3: \\ Countries Dependent on a Single Primary Commodity for Export Earnings}

(Annual average of exports, in dollars, 1992-97)

\begin{tabular}{|c|c|c|c|}
\hline & $\begin{array}{l}50 \text { percent or more } \\
\text { Of export earnings }\end{array}$ & $\begin{array}{l}\text { 20-49 percent } \\
\text { of export earnings }\end{array}$ & $\begin{array}{l}\text { 10-19 percent } \\
\text { of export earnings }\end{array}$ \\
\hline \multicolumn{4}{|l|}{ Middle East } \\
\hline \multirow[t]{4}{*}{ Crude petroleum } & Bahrain, Saudi Arabia & Syrian Arab Rep. & Egypt \\
\hline & Iran, Islamic Rep. Of & United Arab Emirates & \\
\hline & Iraq, Kuwait, Libya & & \\
\hline & $\begin{array}{l}\text { Oman, Qatar, } \\
\text { Yemen Rep. }\end{array}$ & & \\
\hline Aluminum & & & Bahrain \\
\hline \multicolumn{4}{|l|}{ Africa } \\
\hline \multirow[t]{2}{*}{ Crude petroleum } & Angola, Gabon, Nigeria & Cameroon & Algeria \\
\hline & Congo, Rep. & Equatorial Guinea & \\
\hline Natural gas & & Algeria & \\
\hline Iron ore & & Mauritania & \\
\hline Copper & Zambia & & Congo, Dem. Rep. \\
\hline Gold & & Ghana, South Africa & Mali, Zimbabwe \\
\hline $\begin{array}{l}\text { Timber (African } \\
\text { hardwood) }\end{array}$ & & Equatorial Guinea & $\begin{array}{l}\text { Central African Rep. } \\
\text { Swaziland, Gabon, Ghana }\end{array}$ \\
\hline Cotton & & Benin, Chad, Mali, Sudan & Burkina Faso \\
\hline Tobacco & Malawi & Zimbabwe & \\
\hline Arabica coffee & Burundi, Ethiopia & Rwanda & \\
\hline Robusta coffee & Uganda & & Cameroon \\
\hline Cocoa & Sao Tome and Principe & Cote d'Ivoire, Ghana & Cameroon \\
\hline Tea & & & Kenya, Rwanda \\
\hline Sugar & & Mauritius & Swaziland \\
\hline \multicolumn{4}{|c|}{ Western Hemisphere } \\
\hline Crude petroleum & Venezuela & $\begin{array}{l}\text { Ecuador,Trinidad } \\
\text { \&Tobago }\end{array}$ & Colombia, Mexico \\
\hline Copper & & Chile & Peru \\
\hline Gold & & & Guyana \\
\hline Cotton & & & Paraguay \\
\hline \multirow[t]{2}{*}{ Arabica coffee } & & & Colombia, Guatemala \\
\hline & & & $\begin{array}{l}\text { Honduras, Nicaragua, El } \\
\text { Salvador }\end{array}$ \\
\hline Sugar & & $\begin{array}{l}\text { Guyana, } \\
\text { St.Kitts \&Nevis }\end{array}$ & Belize \\
\hline Bananas & & St.Vincent, Honduras & St.Lucia, Costa Rica, Ecuador \\
\hline Fishmeal & & & Peru \\
\hline
\end{tabular}




\begin{tabular}{|c|c|c|c|}
\hline \multicolumn{4}{|c|}{ Europe and Asia and the Pacific } \\
\hline \multirow[t]{3}{*}{ Crude petroleum } & & Azerbaijan, & Indonesia \\
\hline & & Brunei Darussalem & Kazakhstan \\
\hline & & Norway, Russia & Vietnam \\
\hline Natural Gas & Turkmenistan & & \\
\hline Aluminum & & Tajikistan & \\
\hline Copper & & Mongolia & $\begin{array}{l}\text { Kazakhstan, } \\
\text { Papua New Guinea }\end{array}$ \\
\hline Gold & & Papua New Guinea & Uzbekistan \\
\hline Timber (Asian & & Lao P.D.R. & Cambodia, Papua New Guinea \\
\hline hardwood) & & Solomon Islands & Indonesia, Myanmar \\
\hline Timber (softwood) & & & Latvia, New Zealand \\
\hline Copra \& coconut oil & Kiribati & & \\
\hline Cotton & & Pakistan & Azerbaijan, Tajikistan \\
\hline & & Uzbekistan & Turkmenistan \\
\hline
\end{tabular}

Source: Cashin, Liang, and McDermott (1999).

The behavior of primary commodity prices -- including their long-term trends, cycles, and short-run volatility -- has differed considerably from the behavior of manufactured goods. Regarding long-term trends, Raul Prebisch and Hans Singer hypothesized that there would be an ongoing secular deterioration in the relative price of primary commodities in terms of manufactures. They based this prediction on their presumptions that (1) the income elasticity of worldwide demand for primary commodities is considerably less than unity, while that for manufactures exceeds unity, (2) primary commodity markets are competitive "flex-price" markets, whereas those of manufactured goods were characterized by monopolistic, price-setting behavior, and (3) technological change in the commodities industries is likely to proceed more slowly than that in the manufacturing sector, but is more likely to result in downward pressure on prices rather than improved profit margins. In spite of extensive testing in the economic development literature, the empirical evidence regarding 
the PS hypothesis remains mixed. (See, e.g., Reinhart and Wickham (1994) and the references therein.)

There seems to be less controversy about the relative volatility and cyclicity of primary commodity prices. Commodity price volatility has consistently exceeded that of manufactured goods. This is generally attributed to: (1) low price elasticities of both supply and demand for commodities, (2) uncertain supply conditions (due to weather for agricultural products, and discoveries for non-renewable resources), and (3) the competitive, flex-price nature of many commodity markets. As Figure 1 shows, the high volatility of nominal commodity prices relative to manufactures has been true for decades of either high or low volatility. $^{3}$

Some authors have noted that primary commodities seem to have volatility that is the same order of magnitude as the volatility of exchange rates or stock prices. Using data covering the period of 1972-82, Bui and Pippenger (1990) find that primary commodity prices that are determined in the well-organized auction markets (e.g., rubber and tin) were more volatile than exchange rates. This has led economic modelers to suggest that world primary commodity prices should be thought of as "asset prices." See, e.g., Jeff Frankel's (1986) model of commodity price "overshooting" in response to money supply shocks; his model adapts the classic Dornbusch exchange rate overshooting model to explain the volatility of commodity prices (but in a closed economy context).

Both nominal and real commodity prices are procyclical. In fact, nominal commodity prices are sometimes used as a leading indicator of inflation, and touted as a

\footnotetext{
${ }^{3}$ Although this is not apparent in for the series used in constructing Figure 1, Reinhart and Wickham $(1994,186)$ note that, for their dataset, "there is a sustained and sharp increase in the variance of commodity prices [over their sample period 1957:I-1993:II]. The increase is evident in all the indices but is most pronounced in the all commodities and food groupings."
} 
Figure 1. The instability index for manufactures and commodities, 1990-92

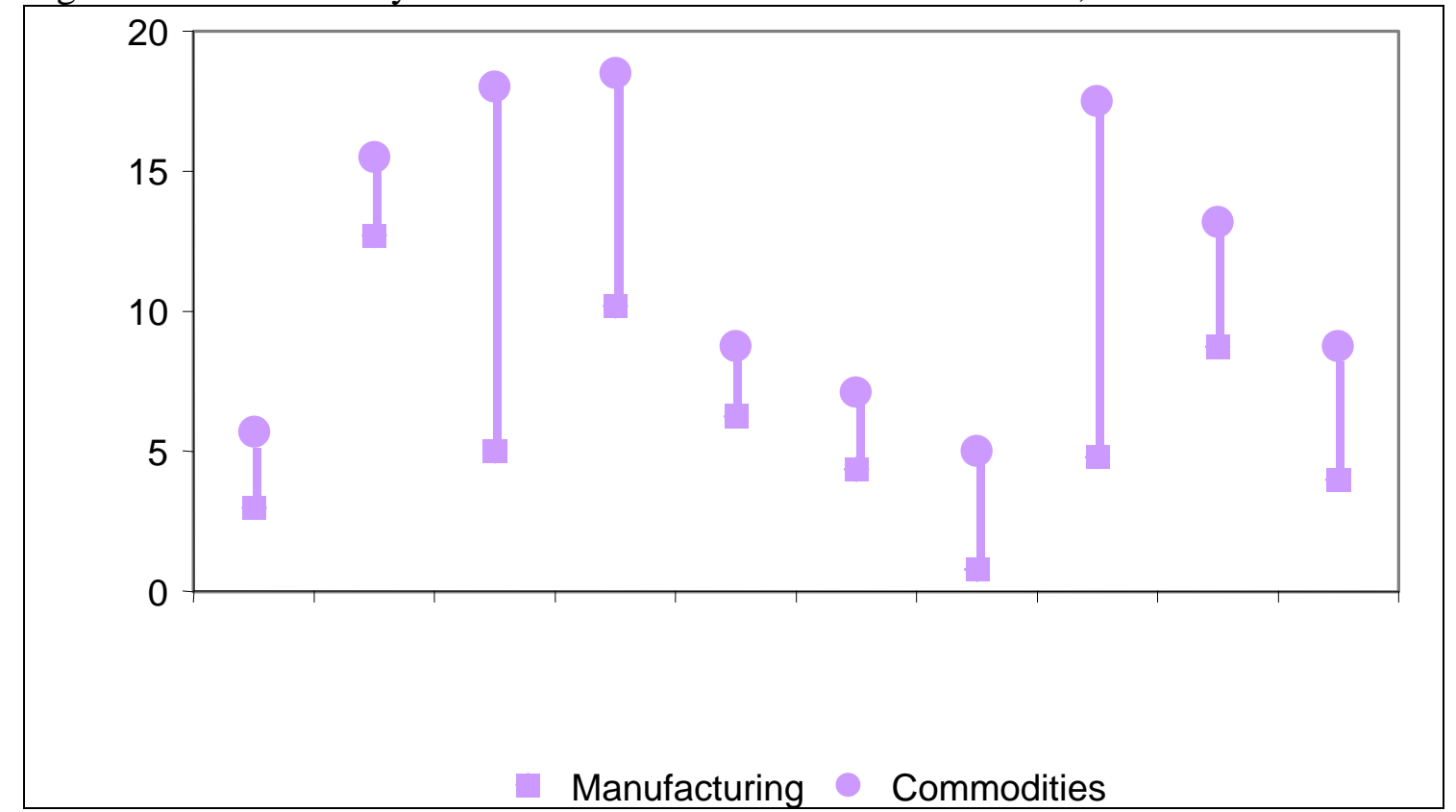

Source: World Bank (1994).

useful intermediate target for monetary policy. For an excellent review of the macroeconomic determinants of commodity prices, see Borensztein and Reinhart (BR)(1994). They note that: "The conventional analysis of commodity markets mimics the empirical strategy applied to other key macroeconomic variables -- namely, to try to identify a stable and predictable relationship between commodity prices and two or three macroeconomic variables.” (p.237) They highlight the important role of changes in a commodity supply index (Q), as well as worldwide industrial production (IPW) and the real U.S. dollar exchange rate (RER) in explaining real commodity prices (y): ${ }^{4}$

$$
\log y=\beta_{0}+\beta_{1} \log (\text { IPW })+\beta_{2} \log (\text { RER })+\beta_{3} \log (\mathrm{Q})
$$

\footnotetext{
${ }^{4}$ See their references for earlier work in a similar vein, including Dornbusch (1985), and Gilbert (1989).
} 
Their estimated commodity price equations are motivated by the so-called "traditional structural approach." It assumes that commodities produced in commodity exporting regions are demanded as intermediate inputs in the production of manufactured goods in the U.S. and other industrial countries. The derived world demand function for commodities is shown to depend on industrial production in the U.S., industrial production in other commodityimporting industrial nations, and the real U.S. dollar exchange rate. As BR $(1994,237$, fn.1) explain, "The role of the real exchange rate of the U.S. dollar in this framework is to correct for the fact that commodity prices are measured by a dollar-denominated index and deflated by a dollar-denominated price index, whereas the relevant measure for the non-U.S. industrial countries is the price of commodities relative to output prices in those countries." BR (1994) emphasize that the traditional structural approach is 'partial equilibrium' in nature in that it treats the real exchange rate and world economic activity, determinants of commodity prices, (both conceptually and empirically) as exogenous. But this is a serious shortcoming. It is increasingly recognized that international commodity markets, including oil but other commodities as well, play an important role in determining or at least affecting post World War II business cycles in the U.S. and other industrial economies, and in transmitting macro shocks internationally. (See, e.g., Beckerman and Jenkinson (1986), Hamilton (1983) and Reinhart (1991).)

Reinhart (1991) develops a real (i.e. non-monetary) model that treats real commodity prices, industrial production, and real exchange rates as endogenously determined in the face of fiscal and commodity supply shocks. BR (1994) cope with the simultaneity bias issue by using the instrumental variables when estimating the commodity price equation in (1) above. Based on a variance decomposition analysis for real commodity prices for the period 1971:I1992:III and three subperiods: 1971:I-1984:IV, 1985:I-1988:IV, and 1989:I-1992:III, BR 
conclude that the "real exchange rate of the U.S. dollar explains a fairly stable proportion of the variance of commodity prices throughout the subperiods." $(1994,256){ }^{5}$

A number of analysts have emphasized the strong link between movements in the dollar exchange rate and the relative price of commodities in terms of manufactures. Hence, it is natural to ask: does only the dollar exchange rate matter? Should we consider the differential effects of the movements in several key currencies? Gilbert (1989) argues convincingly that the appropriate definition of the effective exchange rate is critical in getting meaningful results when studying the impact of exchange rate changes on world commodity prices.

International macroeconomists and policy makers have long been interested in the impact of alternative exchange arrangements on various macroeconomic variables. Mussa (1986) and others have emphasized that flexible exchange rate regimes imply higher volatility of real as well as nominal exchange rates. International macro textbooks contain lengthy discussions of how the international transmission of shocks may be enhanced or mitigated, depending on the nature of the shock (real vs. monetary; internal vs. external), exchange regime in effect, the degree of international capital mobility, etc. Surprisingly, therefore, empirical research has been unable to detect the impact of choice of exchange regime on many, if any, macroeconomic aggregates besides the real exchange rate. See, e.g., Baxter and Stockman (1989), Flood and Rose (1995) and Rogers (1995).

Effects of exchange regime on international trade and financial flows, perhaps via the real exchange rate effect, have also been examined. It has often been conjectured that under flexible exchange rate regimes, export and import prices become more volatile, thereby adding additional risk to export and import transactions. The impact of this additional price

\footnotetext{
${ }^{5}$ Borensztein and Reinhart (1994, p. 259) use an IMF index of the real exchange rate of the United States relative to other industrial countries. It is based on value added deflators in manufacturing.
} 
uncertainty on export and import volumes, however, has been difficult to isolate empirically. ${ }^{6}$ One possible explanation is the increased sophistication of firms in hedging exchange-rateinduced price risks.

There has yet to emerge from international macro-theorists, a general microfoundations model of price stickiness for manufactured goods produced in two industrial countries, using primary commodities produced in LDCs. Without such a framework - and specifically one that includes domestic and foreign monies in a fundamental way, explorations of the impact of the choice of exchange regime on real commodity prices, real exchange rates, and the international transmission of business cycles will be incomplete. Empirical analyzes of the effects of exchange regime on various macro variables will in turn be viewed tentatively, due to the lack of a fully fleshed out analytical framework.

Given these caveats, Cuddington and Liang (CL) (1997) provide some potentially important stylized facts. They consider three alternative datasets on commodity prices covering a number of different exchange regimes over the period from the 1880s to 1996. Exchange regimes were distinguished using either (1) a dummy variable, DUMFLEX, that takes the value of zero during fixed exchange rate episodes and one during flexible exchange rate periods, or (2) a measure of U.S. dollar/SDR volatility. CL find that the volatility of real primary commodity prices has been higher under flexible exchange regimes.

The delineation of exchange regimes in CL implies that all countries shared the same exchange regime, or rather that these regimes are rough characterizations of the international monetary system as a whole. During the Bretton Woods fixed exchange rate period, most countries fixed their exchange rates in terms of U.S. Dollars, which in turn was pegged to the price of gold. Yet, Canada had a flexible exchange rate for much of this period. Similarly,

\footnotetext{
6 We know of no literature that considered the impact of exchange rate uncertainty on exports and imports of commodity trade in isolation.
} 
the post-Bretton Woods period after 1973 is characterized as a floating rate period, even though many LDCs (initially, at least) retained fixed exchange rates. Within Europe, as well, a number of countries adopted exchange rate arrangements exhibiting 'limited flexibility.' Examples include: (1) the so-called "snake in the tunnel" arrangement, which came into effect in 1972, following the 1970 Werner Report; (2) the European Monetary System (EMS) with its ECU-based exchange rate mechanism (ERM), which emerged in 1979; and ultimately (3) the Euro system, which came into existence on January 1, 1999.7

\section{Indicators of Exchange Rate Volatility}

We now turn to the more analytical of our two questions in the Introduction: what effects, if any, will the emergence of the Euro have on the volatility of world primary commodity prices (denominated in U.S. dollars)? The real commodity price equation in (1), and the traditional structural approach that underpins it, provide a way of thinking about this question. How will the emergence of the Euro affect the volatility of world industrial production and/or the volatility of real exchange rates? Conceptually, the emergence of the Euro zone might lead to greater business cycles synchronization within Europe, but not necessarily worldwide. Similarly, real exchange rates between the Euro-11 and the rest of the world may rise or fall. Hence, just based on the traditional structural approach to the macroeconomic determinants of real commodity prices, it is uncertain a priori how the Euro's emergence may impact commodity price volatility.

\footnotetext{
${ }^{7}$ See De Grauwe (1994) and Szasz (1999) for institutional details and historical context.
} 
In order to use historical data to shed some empirical light on the inherently forwardlooking question being addressed in this paper, we ask: were periods of relative stability among the bilateral exchange rates of the Euro-11 countries between 1957 and 1998 associated with relatively stable commodity prices? To address this question we extend Cuddington-Liang (1997), who investigated the extent to which commodity price volatility can be explained by the choice of worldwide exchange regime (measured by a dummy variable indicating the world-wide exchange regime) or dollar exchange rate volatility. During the 1957-1998 period, the US dollar was the dominant currency in the international monetary system. Hence the chosen quantitative proxy for the exchange rate uncertainty in the global market as a whole is the volatility of the US dollar/SDR rate, denoted as var_us. ${ }^{8}$ Volatility is defined here as the square of the period-to-period change in the logarithm of the US dollar/SDR exchange rate.

The IMF's International Financial Statistics (IFS) publication provides the following background on the SDR: "Beginning in July 1974, the value of the SDR is determined by the Fund on the basis of a basket of currencies with each currency assigned a weight in the determination of that value. In the derivation of the SDR value, the currencies in the basket are valued at their market exchange rates for the U.S. dollar, and the U.S. dollar equivalents of each of the currencies are summed to yield the rate of the SDR in terms of the U.S. dollar. The method of calculating the U.S. dollar/SDR exchange rate remains the same, although the number and weights of currencies in the SDR basket have changed over time." (IFS Feb.

\footnotetext{
8 The U.S. dollar/SDR exchange rate, as well as the nominal exchange rates of the other 10 Euro countries against the Deutsche mark, were obtained from the International Financial Statistics (line rf, the period average exchange rate).
} 
1995, pp.x-xi) Since January 1, 1981, the value of the SDR has been based on a basket of five currencies. ${ }^{9}$ The composition and currency amounts in the SDR valuation basket were last revised as of January 1, 1996. It currently contains 0.582 U.S. dollars, 0.446 Deutsche marks, 27.2 Japanese yen, 0.813 French francs, and 0.105 pound sterling. ${ }^{10}$ (IMF Annual Report 1998, p.93, Table 15). Thus, the dollar/SDR rate is currently defined as:

$$
\mathrm{S}(\$ / \mathrm{SDR})=.582+.446 \mathrm{~S}(\$ / \mathrm{DM})+27.2 \mathrm{~S}(\$ / \mathrm{yen})+.813 \mathrm{~S}(\$ / \mathrm{FF})+.105 \mathrm{~S}(\$ / \text { pound })
$$

Given this definition of the USD/SDR exchange rate, it is clear that var_us, which is the square of its period-to-period percentage, will be affected not only by the squares of the percentage changes in the five component currencies, but also their pairwise correlations. ${ }^{11}$ As Fig. 2 shows, the values of var_us were zero, expect for a couple of realignments in the early 1970s, reflecting the exchange rate stability of the Bretton-Woods period. Var_us increased considerably thereafter. ${ }^{12}$

For the question in this paper, an index for the German effective exchange rate vis-àvis the other 10 Euro currencies was constructed by taking the weighted average of the 10

\footnotetext{
9 "Beginning in January 1, 1991, the SDR valuation basket consists of the currencies of the five members having the largest exports of goods and services during the period 1985-89..." (IFS, Feb. 1995, xi)

${ }^{10}$ Given exchange rates as of January 1, 1996, the percentage (value) weights were 39, 21, 18, 11, and 11 percent, respectively.

${ }^{11}$ Note that reductions in the period-to-period percent changes in the bilateral cross rate between Germany and France, say, may or may not produce a reduction in var_us.

${ }^{12}$ Examining Fig.2, we noted that the sterling crisis in the late 1960s does not show up. This is because dollar/SDR rate was fixed during this period. The redefinition of the SDR in terms of a basket of currencies was introduced in July 1974 after the Bretton Woods fixed exchange rate commitment collapsed.
} 
bilateral nominal exchange rate against the German mark. ${ }^{13}$ Our measure of intra-Euro currency volatility, var_euro, is defined as the percentage change of this constructed German effective exchange rate over previous period squared. The formula is analogous to that for the dollar/SDR rate above.

Var_euro is shown in Fig. 3. A comparison of Figures 3 and 4 shows that the behaviors of volatility measures for the US/SDR exchange rate and the Euro-11 exchange rates are quite different over the sample period. The correlation coefficient between the two volatility indices is only 0.06 .

Presumably the emergence of the Euro-zone will be associated with reduced volatility in the var_euro index. The hypothesis to be tested is whether reduced nominal exchange rate volatility within the Euro-11 countries leads to greater stability in real commodity prices, other things equal (including exchange rate volatility in the non-Euro countries).

\section{Volatility of Real Commodity Prices and Major World Currencies}

Following the norm in the commodity price literature, this study examines a real commodity price index, defined as the ratio of the chosen nominal commodity index deflated

\footnotetext{
13 The weights are constructed by taking the average of the ratio of each individual country's exports plus imports over the total sum of trade in the Euro zone over the period of 1969-98 when the trade data is available. The effective exchange rate calculated using GDP weights is quite similar to the index used here.
} 
by the manufacturing unit value (muv) index. The latter is a unit value index for

manufactured good exports from a number of industrial countries. ${ }^{14}$

The IFS reports monthly commodity price indexes for agricultural raw materials,

beverages, fertilizer, food, metals, and petroleum from January 1957 through December

1998. In addition, a sub-category of the food index, the cereals, is also considered since it is

one major item covered by the European Common Agricultural Policy (CAP). Table 4

provides a detailed description of each commodity index and some summary statistics for

their first-differences.

\section{Table 4: \\ Specifications and Summary Statistics for Commodity Prices}

(Jan. 1957 - Dec. 1998)

\begin{tabular}{|c|c|}
\hline \multicolumn{2}{|c|}{ Definition of Commodities } \\
\hline Beverages & coffee, cocoa beans, tea \\
\hline Food & $\begin{array}{l}\text { wheat, maize, rice, soybeans soybean meal, soybean oil, palm oil, coconut } \\
\text { oil, fish meal, groundnut oil, beef, lamb, sugar, bananas }\end{array}$ \\
\hline \multicolumn{2}{|c|}{\begin{tabular}{l|l} 
Cereals & wheat, maize, rice \\
\end{tabular}} \\
\hline Fertilizer & phosphate rock, triple super-phosphate \\
\hline Metals & copper, aluminum, iron ore, tin, zinc, lead \\
\hline Petroleum & crude oil, gasoline, natural gas, heating oil \\
\hline $\begin{array}{l}\text { Agricultural } \\
\text { raw materials }\end{array}$ & hardwood, softwood, cotton, wool, rubber, tobacco, hides \\
\hline \multicolumn{2}{|c|}{$\begin{array}{l}\text { Summary Statistics } \\
\text { for first difference of the MUV-deflated commodity prices indices }\end{array}$} \\
\hline & Median Maximum \\
\hline Beverages & -0.1940 \\
\hline
\end{tabular}

14 The MUV series is obtained from the IMF commodity price database. Some of these exports are flows among industrial countries; some are exports to developing countries. Hence, the MUV is not a perfect measure of the unit value of manufacturing exports to (only) developing countries. By the same token, some industrial countries export primary commodities. It is risky, therefore, to interpret the relative price of commodities (in terms of the MUV) as a measure of any country's terms of trade. Rather the relative price of primary commodities in terms of manufactures should be viewed as a key relative price in the world macroeconomy. 


\begin{tabular}{|l|rrrrrr|} 
Food & -0.0016 & -0.0002 & 0.1420 & -0.1368 & 0.0312 & 6.1128 \\
\hline \multicolumn{1}{|c|}{ Cereals } & -0.0020 & -0.0031 & 0.2862 & -0.1423 & 0.0383 & 10.4097 \\
\hline Fertilizer & -0.0007 & -0.0019 & 1.1183 & -0.5254 & 0.0638 & 201.5273 \\
\hline Metals & -0.0017 & -0.0011 & 0.1259 & -0.2263 & 0.0365 & 7.8668 \\
\hline Petroleum & $1.31 \mathrm{E}-05$ & -0.0017 & 1.2164 & -0.2721 & 0.0828 & 97.7781 \\
\hline $\begin{array}{l}\text { Agricultural } \\
\text { raw materials }\end{array}$ & -0.0003 & 0.0009 & 0.1151 & -0.1219 & 0.0275 & 5.5766 \\
\hline
\end{tabular}

Source: The IMF's International Financial Statistics.

Figure 4 plots the percentage change over previous period (i.e. the first-difference of the natural logarithm) for each real commodity price series. Careful visual examination of Figures 2-4 suggests apparent co-movement between the volatility of beverages, food and agricultural raw materials with the volatility of the US dollar/SDR rate. The volatility of petroleum prices, on the other hand, may be correlated with Euro-11 exchange rate volatility. A more systematic examination of these conjectures is presented in the next section.

\section{Econometric Analysis}

\section{A. Trends in the Commodity Price Series}

Before measuring the temporal variation in the second moments of a time series, it is important to consider alternative specifications of its trend. An ongoing debate among scholars testing the PS hypothesis has been whether real commodity prices are better modeled as trend stationary (TS) or difference stationary (DS) processes. ${ }^{15}$ These two univariate specifications for the trend in a time series, $\log y_{t}$ which is the natural logarithm

\footnotetext{
${ }^{15}$ Using their re-constructed price index to estimate the time trend model, Grilli and Yang (1988) found evidence supporting the PS hypothesis. Cuddington and Urzúa (1989) introduced the unit root issue into the PS debate. Their statistical analysis concluded that there was no secular downward trend in the GY index regardless of whether the DS or TS model is used. However, their results crucially rely on the specification of a change in the mean occurred in 1920. Perron (1990) used "additive outlier" method to deal with the structural break in 1920/1921 and again rejected the unit root hypothesis. Cuddington (1992) considered 26 individual commodities and found 13 of them to be trend stationary, whereas the other 13 were difference stationary.
} 
of real commodity price indices in our context -- can be nested within the following general specification:

$$
\log y_{t}=\alpha+\beta * \text { time }+e_{t}
$$

where $e_{t}$ follows a possibly integrated ARMA process:

$$
(1-\rho L) * A(L) * e_{t}=B(L) * \varepsilon_{t}
$$

$\mathrm{A}(\mathrm{L})$ and $\mathrm{B}(\mathrm{L})$ are autoregressive and moving average lag polynomials. The largest root in the AR polynomial, $\rho$, is factored out for convenience. When $|\rho|<1$, the model (3)-(4) is just a log-linear time trend model with an ARMA error process accounting for the transitory fluctuations around a deterministic trend. For the case of an integrated error process where, by definition, $\rho=1$, the model (3)-(4) collapses to a DS (or 'stochastic trend') model with a stochastic growth rate equal to:

$$
d \log y_{t}=\beta+u_{t}
$$

and a stationary ARMA error process:

$$
A(L) * u_{t}=B(L) * \varepsilon_{t}
$$

In the latter case, $\log y_{t}$ is called a unit root process with (possibly non-zero) drift $\beta$. The error process in (5) is assumed to be stationary, so that fluctuations around the stochastic drift in the series are transitory.

Different detrending methods can differ markedly in the degree to which they filler out particular frequencies (Baxter, 1988), implying that measures of conditional and unconditional volatility may be quite sensitive to the choice of detrending method. Our 
approach is to carry out Phillips-Perron ${ }^{16}(\mathrm{PP})$ unit root tests on each series. If the null hypothesis of a unit root is not rejected, we fit a DS model and consider the volatility in the error process in that specification in our subsequent analysis. If the unit root hypothesis is rejected, we use a TS model instead.

Both Dickey-Fuller and Phillips-Perron unit root tests involve running an auxiliary regression of the form: ${ }^{17}$

$$
d \log y_{t}=\omega+\phi \log y_{t-1}+\theta * \text { time }+\zeta_{t}
$$

and testing the hypothesis that $1-\rho \equiv \phi=0$ using appropriate critical values obtained from Monte Carlo simulations. (The two tests differ in terms of how they cope with serially correlated errors in (7), but this need not concern us here.)

Table 5 reports the results of the Phillips-Perron tests on the real commodity price series. The power of unit root tests, as well as the appropriate critical values, depend on whether an intercept and time trend are included in the regression used to obtain the PP statistics. The tests in Table 5 were based on the general-to-specific methodology (GTS) of first including both a constant and a time trend in the estimation. If the null hypothesis of a unit root is not rejected in the most general specification, the significance of the trend is tested to see if it can be omitted, thereby increasing the power of the unit root test. If the null hypothesis is still not rejected, the significance of the intercept term in the PP regression

\footnotetext{
${ }^{16}$ Since $u_{t}$ is shown to be heteroskedastic later in the study, Phillips-Perron unit root test is more appropriate than the augmented Dickey-Fuller test.

${ }^{17}$ To obtain this equation, multiply (2) by (1- $\left.\mathrm{\rho L}\right)$ to get: $\log y_{t}=[(1-\rho) \alpha-\rho \beta]+\rho \log y_{t-1}+(1-\rho) \beta *$ time $+\zeta_{t}$
} 
is tested to see if it too can be dropped before the PP unit test is re-done on the more parsimonious specification. The third column of the Table indicates whether a time trend (T), an intercept $(\mathrm{C})$, or neither term $(\mathrm{N})$ is included in the PP regression equation chosen using the GTS method (See Enders, 1995, Chapter 4 for detailed discussion of the GTS method.)

As Table 5 indicates, the null hypothesis of unit root is rejected at the 5\% significance level for the series of agricultural raw materials and metals. The tests suggest that these two series do not have unit roots, but rather are (trend) stationary. For all other series, failure to reject the unit root hypothesis suggests that a DS model is a reasonable univariate characterization.

\section{Table 5: \\ Phillips-Perron Unit Root Tests}

\begin{tabular}{|l|r|c|}
\hline & PP $\boldsymbol{s} \tau$ statistic & $\begin{array}{c}\text { FINAL } \\
\text { SPECIFICATION OF } \\
\text { THE PP TEST } \\
\text { (GTS METHOD) }\end{array}$ \\
\hline Beverages & 0.40 & $\mathrm{~N}$ \\
\hline Fertilizer & 0.08 & $\mathrm{~N}$ \\
\hline Food & 0.85 & $\mathrm{~N}$ \\
\hline Cereals & 0.79 & $\mathrm{~N}$ \\
\hline Metals & $-3.35^{*}$ & $\mathrm{~T} \& \mathrm{C}$ \\
\hline Petroleum & -0.21 & $\mathrm{~N}$ \\
\hline $\begin{array}{l}\text { Agricultural Raw } \\
\text { Materials }\end{array}$ & $-4.05^{*}$ & $\mathrm{~T} \& \mathrm{C}$ \\
\hline
\end{tabular}

* indicates rejection of the unit root hypothesis at the 5\% significance level.

Although the focus of the present paper is on volatility, the estimated time trends for the commodity price indices are reported in Table 6 below for the interested reader. If the DS model is chosen, the estimated time trend in the commodity price is the coefficient $\beta$ in 
(5). If the TS model is chosen, because the unit root hypothesis is rejected, the estimated trend in prices is $\beta$ in (3).

\section{B. Commodity Price Volatility and Exchange Rate Fluctuation}

In many ways, commodity prices behave like asset prices. It has long been observed that asset returns tend to be platykurtic (i.e. they exhibit "fat tails"). Volatility clustering is also common. That is, large changes tend to be followed by large changes, and small changes tend to be followed by small changes. Visual inspection of Fig. 4 reveals this volatility clustering quite clearly. In this study, a univariate generalized autoregressive conditional heteroskedastic (GARCH) model is used to account for time-varying conditional variance structure of the errors in the detrended series. The hypothesis of interest is the extent to which changes in volatility for the U.S. dollar and the Euro-11 currencies are associated with changes in the volatility of world commodity prices (deflated).

\section{(a) GARCH Models}

In what follows, we assume that real primary commodity prices can be characterized by a deterministic or stochastic time trend model with an ARMA error process as in (3)-(4) or (5)(6), depending on the outcome of the unit root tests in Table $5 .{ }^{18}$ To capture the persistence

\footnotetext{
${ }^{18}$ Because it is well known that unit root tests have low power, we tried different specifications of the trend equation when estimating the GARCH equations. Our final results do not appear to be particularly sensitive to the detrending methods used.
} 
in the conditional variance of prices, the innovations $\varepsilon_{t}$ in (4) or (6) are assumed to follow a $\operatorname{GARCH}(\mathrm{p}, \mathrm{q})$ process, as in Bollerslev (1986):

$$
\begin{gathered}
\varepsilon_{t} \mid I_{t-1} \sim N\left(0, h_{t}\right) \\
h_{t}=\delta+\sum_{i=1}^{p} \alpha_{i} \varepsilon_{t-i}^{2}+\sum_{i=1}^{q} \beta_{i} h_{t-i}
\end{gathered}
$$

where $I_{t-1}$ is the information set through time t- 1 . The $\varepsilon_{\mathrm{t}}$ 's are serially uncorrelated (but not stochastically independent because they are related through their second moments).

According to (9), the variance of $\varepsilon_{\mathrm{t}}$ at time $\mathrm{t}$ depends on past news about volatility (the lagged $\varepsilon_{\mathrm{t}-\mathrm{i}}{ }^{2}$ terms) and past forecast variance (the $h_{t-i}$ terms). ${ }^{19}$ A sufficient condition for well-defined variance and covariance (including non-negative variance) is that all coefficients in equation (9) lie inside the unit circle. For example, in a $\operatorname{GARCH}(1,1)$ process, it requires $\alpha>0, \beta>0$, and $\alpha+\beta<1$.

\section{(b) Empirical Results}

This sub-section first examines whether GARCH provides a good description for the behavior of the six monthly commodity price series, ignoring the possible nominal exchange rate volatility effects on the conditional variance. Table 6 presents the estimated coefficients for the univariate commodity price models with GARCH error processes. Note that the GARCH effects are significant for all commodities/indices. The strength of this significance

\footnotetext{
19 The inclusion of lagged conditional variances distinguishes the GARCH model from Engle's (1982) ARCH model, and might be motivated as capturing some sort of adaptive learning mechanism. The GARCH specification is more parsimonious and entails fewer coefficient restrictions than the ARCH model.
} 
is one indication of the appropriateness of the GARCH specification for the commodity price data. For most of the monthly commodity price series, $\operatorname{GARCH}(1,1)$ provides a sufficiently good fit, as it does typically for financial market variables. Diagnostic checks (correlograms and $\mathrm{ARCH}$ LM tests) confirm that there is no further serial correlation, nor ARCH effects, in the residuals after fitting the ARMA error processes reported in the Table. The sum $\alpha+\beta$ measures the persistence of volatility shocks. For most commodity series, this sum is very close to unity, implying that volatility shocks die out rather slowly.

\section{Table 6: \\ Univariate Models with GARCH(1,1) Error Processes Jan. 1957 Dec. 1998}

\begin{tabular}{|c|c|c|c|c|}
\hline & $\delta \times 10^{3}$ & $\alpha$ & $\beta$ & Log likelihood \\
\hline \multirow[t]{2}{*}{ Beverages } & $\begin{array}{l}0.05 \\
(2.47)\end{array}$ & $\begin{array}{l}0.16 \\
(5.17)\end{array}$ & $\begin{array}{l}0.83 \\
(29.93)\end{array}$ & 866.73 \\
\hline & \multicolumn{4}{|c|}{$\begin{array}{c}d \log _{\mathrm{t}}=\underset{(-0.95)}{-0.0025+\mathrm{e}_{\mathrm{t}}} \text { where } \quad(1-0.33 \mathrm{~L}) \mathrm{e}_{\mathrm{t}}=\varepsilon_{\mathrm{t}} \\
(7.17)\end{array}$} \\
\hline \multirow[t]{2}{*}{ Fertilizer } & $\begin{array}{l}0.04 \\
(5.54)\end{array}$ & $\begin{array}{l}0.0002 \\
(1.35)\end{array}$ & $\begin{array}{l}0.99 \\
(396.32)\end{array}$ & 714.12 \\
\hline & \multicolumn{4}{|c|}{$\begin{aligned} d \log _{\mathrm{t}}= & -0.001+\mathrm{e}_{\mathrm{t}} \\
& (-0.26)\end{aligned}$} \\
\hline \multirow[t]{2}{*}{ Food } & $\begin{array}{l}0.01 \\
(1.89)\end{array}$ & $\begin{array}{l}0.11 \\
(5.09)\end{array}$ & $\begin{array}{l}0.88 \\
(47.16)\end{array}$ & 1137.86 \\
\hline & \multicolumn{4}{|c|}{$\begin{array}{cc}d \log _{\mathrm{t}}= & -0.002+\mathrm{e}_{\mathrm{t}} \\
(-1.53) & \text { where } \mathrm{e}_{\mathrm{t}}=(1+0.32 \mathrm{~L}) \varepsilon_{\mathrm{t}} \\
(6.66)\end{array}$} \\
\hline \multirow[t]{2}{*}{ Cereals } & $\begin{array}{l}-0.03 \\
(-3.24)\end{array}$ & $\begin{array}{l}0.11 \\
(5.69)\end{array}$ & $\begin{array}{l}0.88 \\
(42.19)\end{array}$ & 1005.40 \\
\hline & \multicolumn{4}{|c|}{$\begin{array}{c}\text { dlogy }_{\mathrm{t}}=-0.0027+\mathrm{e}_{\mathrm{t}} \\
(-1.33)\end{array}$} \\
\hline \multirow[t]{2}{*}{ Metals } & $\begin{array}{l}0.15 \\
(6.52)\end{array}$ & $\begin{array}{l}0.22 \\
(4.90)\end{array}$ & $\begin{array}{l}0.67 \\
(13.68)\end{array}$ & 1017.43 \\
\hline & \multicolumn{4}{|c|}{$\begin{array}{c}\log _{\mathrm{t}}=-4.23-0.0013 * \text { time }+\mathrm{e}_{\mathrm{t}} ; \\
\quad(-30.35)(-3.52)\end{array}$} \\
\hline \multirow[t]{2}{*}{ Petroleum } & $\begin{array}{l}4.07 \\
(4.72)\end{array}$ & $\begin{array}{l}0.21 \\
(3.25) \\
\end{array}$ & $\begin{array}{l}0.25 \\
(1.54)\end{array}$ & 564.01 \\
\hline & \multicolumn{4}{|c|}{$\begin{array}{cc}d \log _{\mathrm{t}}= & 0.0026+\mathrm{e}_{\mathrm{t}} ; \quad(1+0.38 \mathrm{~L}) \mathrm{e}_{\mathrm{t}}=(1+0.64 \mathrm{~L}) \varepsilon_{\mathrm{t}} \\
(0.36) & (-2.14)\end{array}$} \\
\hline
\end{tabular}




\begin{tabular}{|c|c|c|c|c|}
\hline $\begin{array}{l}\text { Agricultural } \\
\text { Raw Materials }\end{array}$ & $\begin{array}{l}0.02 \\
(2.41)\end{array}$ & $\begin{array}{l}0.17 \\
(4.85)\end{array}$ & $\begin{array}{l}0.82 \\
(27.04)\end{array}$ & 1158.65 \\
\hline & $\log _{\mathrm{t}}$ & $\begin{array}{l}-4.55+\mathrm{e} \\
350.97)\end{array}$ & $\begin{array}{r}(1-0.5 \\
(-0 .\end{array}$ & $\begin{array}{r}+0.06 \mathrm{~L}^{1} \\
(4.96)\end{array}$ \\
\hline
\end{tabular}

Note: t-statistics in parentheses.

To examine our main question in this paper, we now consider the potential importance of variables capturing the degree of nominal exchange rate volatility in the conditional variance equations estimated in Table 6. The conditional variance of $\varepsilon_{\mathrm{t}}$ in (9) is therefore replaced with:

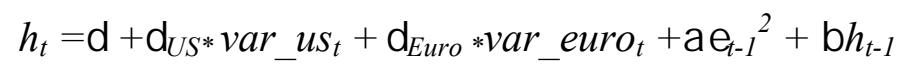

where var_us and var_euro are the indices for the Dollar/SDR and Euro-11 exchange rate volatility, respectively. We carry out a model selection exercise to decide whether either or both of the exchange rate volatility variables should be included. This is done by estimating the version of (10), as well as restricted version where $\delta_{U S}=0, \delta_{\text {Euro }}=0$, or $\delta_{U S}=\delta_{\text {Euro }}=0$. The latter restrictions, of course, indicate that nominal dollar exchange rate and/or Euro-11 exchange rate volatilities have insignificant effects on world commodity price volatility.

The likelihood ratio tests used to examine these restrictions in the GARCH specification (10) are reported in Table 7. The restrictions $\delta_{U S}=\delta_{E u r o}=0$ are rejected at less than $5 \%$ level for every commodity price indices. Column 3 and 4 report the likelihood ratio statistics for the restrictions $\delta_{U S}=0$ and $\delta_{E u r o}=0$, respectively. The results indicate that both the dollar exchange rate and intra-Euro exchange rates fluctuations have significant impacts on the volatility of cereals, petroleum, and metals prices. On the other hand, the price volatilities for beverages, food and agricultural raw materials depend only on the volatility of the U.S. dollar/SDR exchange rate. Interestingly, the volatility of fertilizer prices does not 
depend on the volatility of the dollar/SDR exchange rate once the volatility of the Euro-11 currencies is taken into account.

\section{Table 7: \\ The Likelihood Ratio Statistics for the Restricted and Unrestricted Models}

\begin{tabular}{|l|r|r|r|}
\hline & Ho: $\boldsymbol{\delta}_{\text {Euro }}=\boldsymbol{0}$ & Ho: $\boldsymbol{\delta}_{U S}=\mathbf{0}$ & Ho: $\delta_{U S}=\boldsymbol{\delta}_{\text {Euro }}=\mathbf{0}$ \\
\hline Beverage & 0.60 & $\mathbf{1 3 . 3 2 *}$ & $\mathbf{1 4 . 1 2 *}$ \\
\hline Fertilizer & $\mathbf{2 8 9 . 9 9 *}$ & -155.97 & $\mathbf{2 4 2 . 9 8 *}$ \\
\hline Food & 0.25 & $\mathbf{1 4 . 2 9}$ & $\mathbf{1 5 . 4 1 *}$ \\
\hline Cereals & $\mathbf{6 . 6 5 *}$ & $\mathbf{2 5 . 9 6 *}$ & $\mathbf{3 3 . 9 3 *}$ \\
\hline Metals & $\mathbf{6 4 . 7 1 *}$ & $\mathbf{1 0 . 3 0 *}$ & $\mathbf{6 5 . 9 2 *}$ \\
\hline Petroleum & $\mathbf{5 2 7 . 0 6}^{*}$ & $\mathbf{2 0 6 . 5 3 *}$ & $\mathbf{5 3 5 . 7 2 *}$ \\
\hline Ag. Raw Materials & 1.02 & $\mathbf{7 . 4 4 \#}$ & $\mathbf{7 . 4 7 \#}$ \\
\hline
\end{tabular}

* (\#) indicates rejection of the null at the 5\% (10\%) significance level. The statistic has a chisquare distribution with the degree of freedom equal to the number of restrictions.

If either $\delta_{U S}$ or $\delta_{E u r o}$ are found to be insignificantly different from zero, the associated exchange rate volatility variable is dropped when estimating the final specification for (10) reported below. Based on the likelihood ratio tests in Table 7 (and in order to conserve space), a GARCH model with (i) both var_us and var_euro, (ii) var_us alone, or (iii) var_euro alone was reported in Table 8 for each commodity group. The characterizations of the means of the various price processes [in (3) or (4), plus (7)] remain similar to those in Table 6 . The t-statistics on $\delta_{U S}$ and/or $\delta_{\text {Euro }}$-- the coefficients on the dollar/SDR and Euro exchange rate volatility measures, respectively -- are statistically different from zero at $5 \%$ significance level for every price series except for the price series of agricultural raw materials, which is only at the $10 \%$ significance level. Moreover, the size 
and sign of the estimated $\delta_{\text {US }}$ and/or $\delta_{\text {Euro }}$ parameters indicate how the nominal exchange rate fluctuations affect the commodity price volatility. Since $\delta_{U S}$ and $\delta_{E u r o}$ are significantly positive, there is evidence that the volatility of nominal exchange rates have been positively associated with the volatility of real commodity prices.

\section{Table 8: \\ Accounting for Exchange Rate Fluctuations in the GARCH(1,1) Model}

\begin{tabular}{|c|c|c|c|c|c|}
\hline & $\delta \times 10^{3}$ & $\delta \delta_{U S}$ & $\delta_{\text {Euro }}$ & $\alpha$ & $\beta$ \\
\hline \multirow[t]{2}{*}{ Beverages } & $\begin{array}{l}0.04 \\
(2.18)\end{array}$ & $\begin{array}{l}0.46 \\
\left(2.90^{* *}\right)\end{array}$ & & $\begin{array}{l}0.14 \\
(4.74)\end{array}$ & $\begin{array}{l}0.83 \\
(27.17)\end{array}$ \\
\hline & \multicolumn{5}{|c|}{$\begin{array}{cc}d \log _{\mathrm{t}}=-0.0031+\mathrm{e}_{\mathrm{t}} & \text { where }(1-0.32 \mathrm{~L}) \mathrm{e}_{\mathrm{t}}=\varepsilon_{\mathrm{t}} \\
(-1.30) & (6.83)\end{array}$} \\
\hline \multirow[t]{2}{*}{ Fertilizer } & $\begin{array}{l}-1.66 \mathrm{E}-03 \\
(-1.54)\end{array}$ & & \begin{tabular}{|l|l|}
0.46 \\
$(32.04 * *)$
\end{tabular} & $\begin{array}{l}2.30 \mathrm{E}-03 \\
(6.96)\end{array}$ & $\begin{array}{l}0.98 \\
(633.26) \\
\end{array}$ \\
\hline & \multicolumn{5}{|c|}{$\begin{aligned} & d \operatorname{dog}_{\mathrm{t}}=-0.002+\mathrm{e}_{\mathrm{t}} \\
&(-0.11)\end{aligned}$} \\
\hline \multirow[t]{2}{*}{ Food } & $\begin{array}{l}0.01 \\
(2.59)\end{array}$ & $\begin{array}{l}0.18 \\
(3.15 * *)\end{array}$ & & $\begin{array}{l}0.05 \\
(2.99)\end{array}$ & $\begin{array}{l}0.91 \\
(39.30)\end{array}$ \\
\hline & \multicolumn{5}{|c|}{$\begin{array}{cc}\operatorname{dlog}_{\mathrm{t}}=-0.0019+\mathrm{e}_{\mathrm{t}} & \text { where } \mathrm{e}_{\mathrm{t}}=(1+0.34 \mathrm{~L}) \varepsilon_{\mathrm{t}} \\
(-1.39) & (7.91)\end{array}$} \\
\hline \multirow[t]{2}{*}{ Cereals } & \begin{tabular}{|l|}
0.02 \\
$(2.22)$ \\
\end{tabular} & $\begin{array}{l}0.36 \\
(3.73 * *)\end{array}$ & \begin{tabular}{|l|l|}
0.13 \\
$(3.82 * *)$
\end{tabular} & $\begin{array}{l}0.02 \\
(1.78) \\
\end{array}$ & $\begin{array}{l}0.91 \\
(37.10)\end{array}$ \\
\hline & \multicolumn{5}{|c|}{$\begin{array}{c}d \log _{\mathrm{t}}=-0.0024+\mathrm{e}_{\mathrm{t}} \quad \text { where } \\
(-1.24)\end{array}$} \\
\hline \multirow[t]{2}{*}{ Metals } & $\begin{array}{l}2.72 \mathrm{E}-03 \\
(1.51)\end{array}$ & $\begin{array}{l}0.29 \\
(2.22 * *)\end{array}$ & $\begin{array}{l}0.64 \\
(9.67 * *)\end{array}$ & $\begin{array}{l}0.30 \\
(7.07)\end{array}$ & $\begin{array}{l}0.70 \\
(28.17)\end{array}$ \\
\hline & \multicolumn{5}{|c|}{$\begin{array}{c}\log _{\mathrm{t}}=-4.25-0.001 * \text { time }_{\mathrm{t}}+\mathrm{e}_{\mathrm{t}} ; \\
(-84.58)(-4.59)\end{array}$} \\
\hline \multirow[t]{2}{*}{ Petroleum } & $\begin{array}{l}1.508 \mathrm{E}-04 \\
(0.79)\end{array}$ & $\begin{array}{l}2.68 \\
\left(25.86^{* *}\right)\end{array}$ & \begin{tabular}{|l|l}
1.04 \\
$(7.13 * *)$
\end{tabular} & $\begin{array}{l}0.02 \\
(4.18)\end{array}$ & $\begin{array}{l}0.89 \\
(158.20)\end{array}$ \\
\hline & \multicolumn{5}{|c|}{$\begin{array}{cc}\operatorname{dlog}_{\mathrm{t}}=0.001+\mathrm{e}_{\mathrm{t}} ; & (1+0.42 \mathrm{~L}) \mathrm{e}_{\mathrm{t}}=(1+0.67 \mathrm{~L}) \varepsilon_{\mathrm{t}} \\
(-2.24) & (-3.13)\end{array}$} \\
\hline \multirow[t]{2}{*}{\begin{tabular}{|l|} 
Raw \\
Materials \\
\end{tabular}} & $\begin{array}{l}0.02 \\
(2.78) \\
\end{array}$ & $\begin{array}{l}0.14 \\
(1.92 *) \\
\end{array}$ & & $\begin{array}{l}0.12 \\
(4.09) \\
\end{array}$ & $\begin{array}{l}0.83 \\
(24.38) \\
\end{array}$ \\
\hline & \multicolumn{5}{|c|}{$\begin{array}{cc}\log _{\mathrm{t}}=-4.55+\mathrm{e}_{\mathrm{t}} ; & \left(1-0.97 \mathrm{~L}+0.06 \mathrm{~L}^{13}\right) \mathrm{e}_{\mathrm{t}}=(1+0.24 \mathrm{~L}) \varepsilon_{\mathrm{t}} \\
(-354.69) & (62.23) \quad(-4.84)\end{array}$} \\
\hline
\end{tabular}


* indicates significant at the $10 \%$ significance level.

** indicates significant at the 5\% significance level.

For four commodity groups -- cereals, fertilizer, metals and petroleum, the intra-Euro exchange rate volatility has had statistically significant, positive effects on price volatility. Interestingly, the conditional volatility of the relative prices of fertilizer has been closely associated only with the volatility of the intra-Euro nominal exchange rates. On the other hand, both the US dollar and Euro-11 exchange rate volatility has influenced the conditional volatility of the relative prices of cereals, metals, and petroleum products. The relative magnitude of influence from the two sources of exchange rate fluctuations, however, differs among cereals, metals and petroleum products.

\section{Assessing the Economic Significance of Euro Volatility on Commodity Price Volatility}

Although the previous Section indicates that exchange rate volatility measures have, in some cases, had statistically significant effects on commodity price volatility, one would like to assess their economic significance. For example, the EU's Common Agricultural Policy has operated a series of target and intervention prices aimed at the market for cereals. Thus, one might ask: what has been the impact of Euro-11 exchange rate on the volatility of cereal prices? Are the effects large enough to warrant consideration in policy discussions over the future impacts of the Euro? This section proposes a methodology for addressing this question. 
Consider the GARCH model for cereal prices in Table 8, where both var_us and var_euro are statistically significant. First, we save the estimated conditional variance series $\mathrm{h}_{\mathrm{t}}$ [see (10)] for the estimated GARCH model. Next, we calculate the extent to which var_eurot contributes to $h_{t}$ in each period, assuming the historical series for var_us remains unchanged. ${ }^{20}$ The initial impact of var_euro $t_{t}$ on conditional volatility $h_{t}$ in (10) equals impulse $_{t}=\delta_{\text {Euro }} *$ var_euro $_{t}$. These impulses are then perpetrated through the AR(1) process in the conditional variance equation to determine the cumulative effect on the conditional variance. That is, cum $_{\mathrm{t}}==\delta_{\text {Euro }} *$ var_euro $_{\mathrm{t}}+\beta^{*} \mathrm{cum}_{\mathrm{t}-1}$.

Figure 5 shows the conditional variance series for cereals, along with the impulse and cum series, which show the contribution of var_euro to the conditional variance in each period. Note that the contribution of var_euro to the conditional variance in cereal prices is higher in the 1970s through the early 1980s than it is in the mid-1980s and early 1990s when the Euro-11 exchange rate was less volatile. Figure 6 shows the impulse and cumulative effects of var_eurot, respectively, as percentages of the conditional variance in the same period. During the 1970s, for example, the Euro-11 volatility explains roughly $20 \%$ if we use the $\mathrm{cum}_{t} / \mathrm{h}_{\mathrm{t}}$ measure. In the 1960s, this ratio ranged from 20-40 percent.

From this figure, one might conclude that reducing Euro-11 volatility from the levels seen in the 1970s to zero might be expected to reduce the conditional volatility of cereals prices by roughly $20 \%$. Suppose, on the other hand, one considers the modest volatility of the Euro-11 under the EMS in the late 1980s and early 1990s as the benchmark. Relative to this situation, there will be rather limited marginal gains in terms of reduced cereal price

\footnotetext{
${ }^{20}$ Given that the correlation between var_us and var_euro in the data is only 0.056 , this seems unobjectionable.
} 
volatility when Euro-11 is reduced to zero - the ultimate consequence of adopting a single currency in the Euro-11 zone.

\section{Reverse Causality?}

Some readers of the initial draft of this paper questioned whether there might be reverse causality in the volatility relations described in the previous section. In particular, is it possible that episodes of higher commodity price volatility led to greater exchange rate volatility? For example, it seems plausible that higher petroleum price volatility in the early 1970s induced a shift in exchange rate regimes toward greater flexibility.

To explore the reverse causality issue, we estimated univariate time series models for the logs of the dollar/SDR exchange rate and the Euro-11 exchange rate allowing for GARCH error processes. As the exchange rate series are clearly integrated processes where, by definition, $\rho=1$, this amounts to estimating a DS model where $y_{t}$ is now the nominal exchange rate (either the dollar/SDR rate or the Euro-11 rate). The innovations in the error process in (6) are assumed to follow a GARCH process as in (8)-(9).

The seven commodity price volatility measures in Table 9 below were then added to the GARCH equation (9) to get:

$$
h_{t}=\delta_{1}+\delta_{2} * v a r \_p e t r o l+\delta_{3} * v a r \_b e v+\quad+\delta_{7} * v a r \_m e t a l+\alpha \varepsilon_{t-1}^{2}+\beta h_{t-1}
$$

Table 9 compares the values of the log likelihood functions of various specifications involving subsets of the seven commodity volatility measures. Specification 1 contains all 
seven commodity volatility variables on the right-hand side of the conditional variance equation. Since there are so many combinations for the right-hand side specifications, the table only shows the results of dropping one variable at a time from specification 1.

Specification 8 is the simple GARCH model with no commodity volatility variables in the conditional variance equation for the nominal exchange rate series. The specifications including the commodity volatility measures are generally implausible. While individual coefficients are sometimes significant and other times insignificant, they often have a negative sign. This would imply that higher commodity volatility is associated with lower, not higher, exchange rate volatility. This is the opposite of the effect that skeptics conjectured at the beginning of this section. Moreover, the inclusion of commodity volatility measures in either the dollar or Euro exchange rate equations invariably reduced the value of the log-likelihood function. ${ }^{21}$ This suggestions that the simple GARCH specification for the two nominal exchange rate series, ignoring commodity price volatility measures, provides the best univariate specification.

\footnotetext{
${ }^{21}$ Note that it is theoretically possible for the value of the log-likelihood to fall when additional terms are added to the conditional variance equation. This occurs in situations when the coefficient on some of the exogenous determinants of the conditional variance are negative.
} 
Table 9A:

Signs of coefficients and log-likelihood for various specifications Using dollar (dlus_sdr) exchange rate as the independent variable in the conditional variance equation

\begin{tabular}{|l|l|l|l|l|l|l|l|l|}
\hline Specification & $\begin{array}{l}\text { Var- } \\
\text { petrol }\end{array}$ & $\begin{array}{l}\text { Var- } \\
\text { bev }\end{array}$ & $\begin{array}{l}\text { Var- } \\
\text { rawmat }\end{array}$ & $\begin{array}{l}\text { Var- } \\
\text { food }\end{array}$ & $\begin{array}{l}\text { Var- } \\
\text { cereal }\end{array}$ & $\begin{array}{l}\text { Var- } \\
\text { fert }\end{array}$ & $\begin{array}{l}\text { Var- } \\
\text { metal }\end{array}$ & $\begin{array}{l}\text { Log- } \\
\text { likelihood }\end{array}$ \\
\hline 1 & - & - & + & - & - & - & - & 1540 \\
\hline 2 & - & - & + & - & - & - & & 1539 \\
\hline 3 & - & + & + & + & + & & & 1622 \\
\hline 4 & - & - & + & + & & & & 1739 \\
\hline 5 & - & - & + & & & & & 1547 \\
\hline 6 & - & - & & & & & & 1540 \\
\hline 7 & - & & & & & & & 1539 \\
\hline 8 & & & & & & & & $\mathbf{1 7 0 8}$ \\
\hline
\end{tabular}

Table 9B:

Signs of coefficients and log-likelihood for various specifications Using the Euro-11 exchange rate (dlneer_dm) as the independent variable in the conditional variance equation

\begin{tabular}{|l|l|l|l|l|l|l|l|l|}
\hline Specification & $\begin{array}{l}\text { Var- } \\
\text { petrol }\end{array}$ & $\begin{array}{l}\text { Var- } \\
\text { bev }\end{array}$ & $\begin{array}{l}\text { Var- } \\
\text { rawmat }\end{array}$ & $\begin{array}{l}\text { Var- } \\
\text { food }\end{array}$ & $\begin{array}{l}\text { Var- } \\
\text { cereal }\end{array}$ & Var-fert & $\begin{array}{l}\text { Var- } \\
\text { metal }\end{array}$ & $\begin{array}{l}\text { Log- } \\
\text { Likelihood }\end{array}$ \\
\hline 1 & - & - & + & + & - & + & - & 1668 \\
\hline 2 & - & - & + & + & - & + & & 1667 \\
\hline 3 & - & - & + & + & - & & & 1672 \\
\hline 4 & - & - & + & + & & & & 1688 \\
\hline 5 & - & - & + & & & & & 1681 \\
\hline 6 & - & - & & & & & & 1673 \\
\hline 7 & - & & & & & & & 1702 \\
\hline 8 & & & & & & & & \\
\hline
\end{tabular}




\section{Concluding Remarks}

Our econometric analysis provides evidence that episodes of internal stability of exchange rates among the 11 Euro countries during 1957-98 were associated with periods of lower real commodity price volatility. Judging from the relative magnitudes of the $\delta_{\text {Euro }}$ coefficients in the GARCH specifications, these stabilizing effects are particularly significant for fertilizer, metals and petroleum, and to a lesser degree, cereals. A reasonable inference, therefore, is that the establishment of the Euro on January 1, 1999 should contribute to reduced volatility of world commodity prices, other things equal. This contribution will presumably be very small if we use the EMS period of euro-11 stability as our reference point. If , on the other hand, we use as a benchmark the 1970s when euro-11 exchange rate volatility was relative high, the effects of reducing Euro-11 exchange rate volatility to zero (by adopting a single currency) appear correspondingly larger.

What are the mechanisms through which this stabilizing influence operates? We offer some speculative answers. The existence of EMU implies smaller monetary and fiscal shocks among the Euro-11 countries, thereby reducing the fluctuations on world aggregate demand and indirectly the demand for primary commodities, which are important intermediate inputs in global production.

This paper has focused on the impact that the emergence of the Euro will have on the volatility of world commodity prices. The reverse question may also be worth pursing in future research: What impact are periodic commodity price shocks likely to have on the sustainability of the Euro system? Are Euro countries going to be more or less susceptible to 
commodity price shocks as members of the Euro zone than they would have been under more flexible exchange rate arrangements? If countries give up the flexibility of responding to external commodity price shocks by adjusting their exchange rates, will the unemployment costs of adjusting to these shocks rise for countries in the Euro zone? Some indication of the likely magnitude of such shocks for intra-Euro zone adjustment could presumably be gleaned from the commodity trade (oil and non-oil) composition of exports and imports of Euro zone and non-Euro zone countries. It would be interesting to assess the implications of periodic commodity price shocks for fiscal transfers within the EU. There may also be direct implications for the intra-EU flows of commodities and financial support under the CAP. The findings of this study are important for the on-going debate on the desirability of alternative exchange systems. One of the main reasons why economists care about the regime-dependent behavior of real macroeconomic variables is due to the so-called social inefficiency associated with the floating exchange rates (Hallwood and MacDonald, 1994). If there are nominal rigidities in goods prices, nominal exchange rate changes lead to changes in real exchange rates. Moreover, if goods with different underlying market structures adjust to exchange rates changes differently, the relative prices of two traded goods will also change. Such changes may result in inefficient allocation of goods and services. 
Figure 2: Volatility of the US Dollar/SDR Exchange Rate

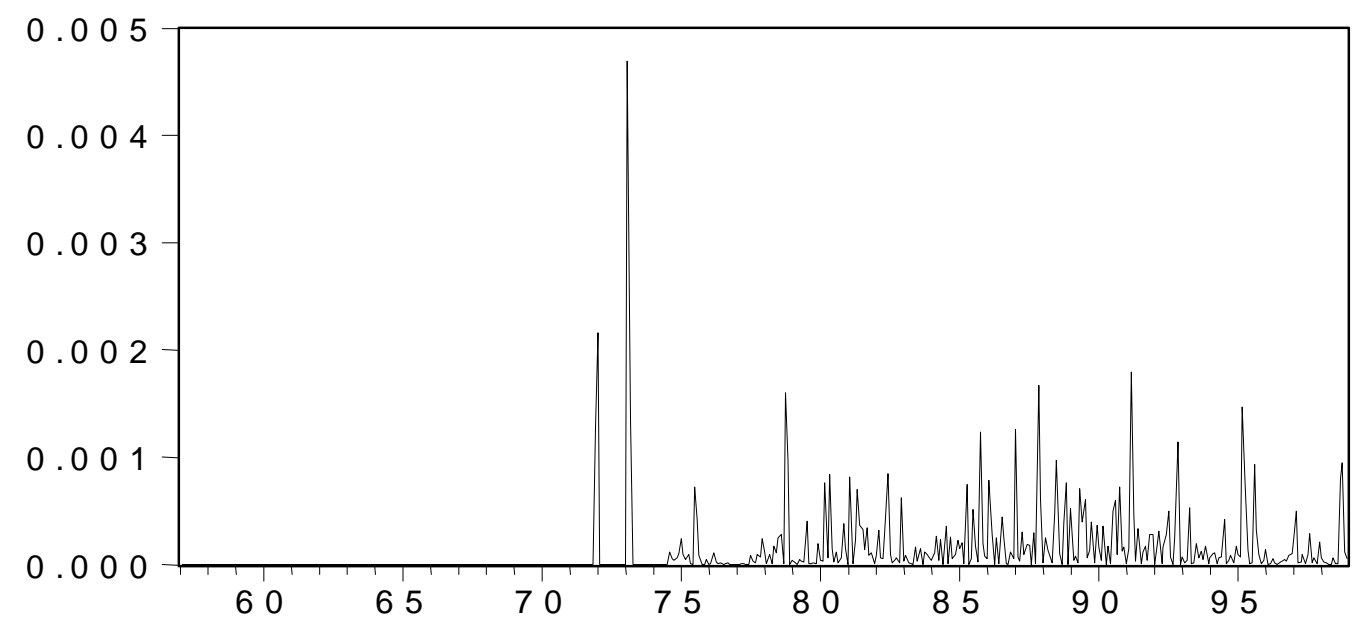

Figure 3: Volatility of the Euro-11 Currencies (vis-à-vis the Deutschmark)

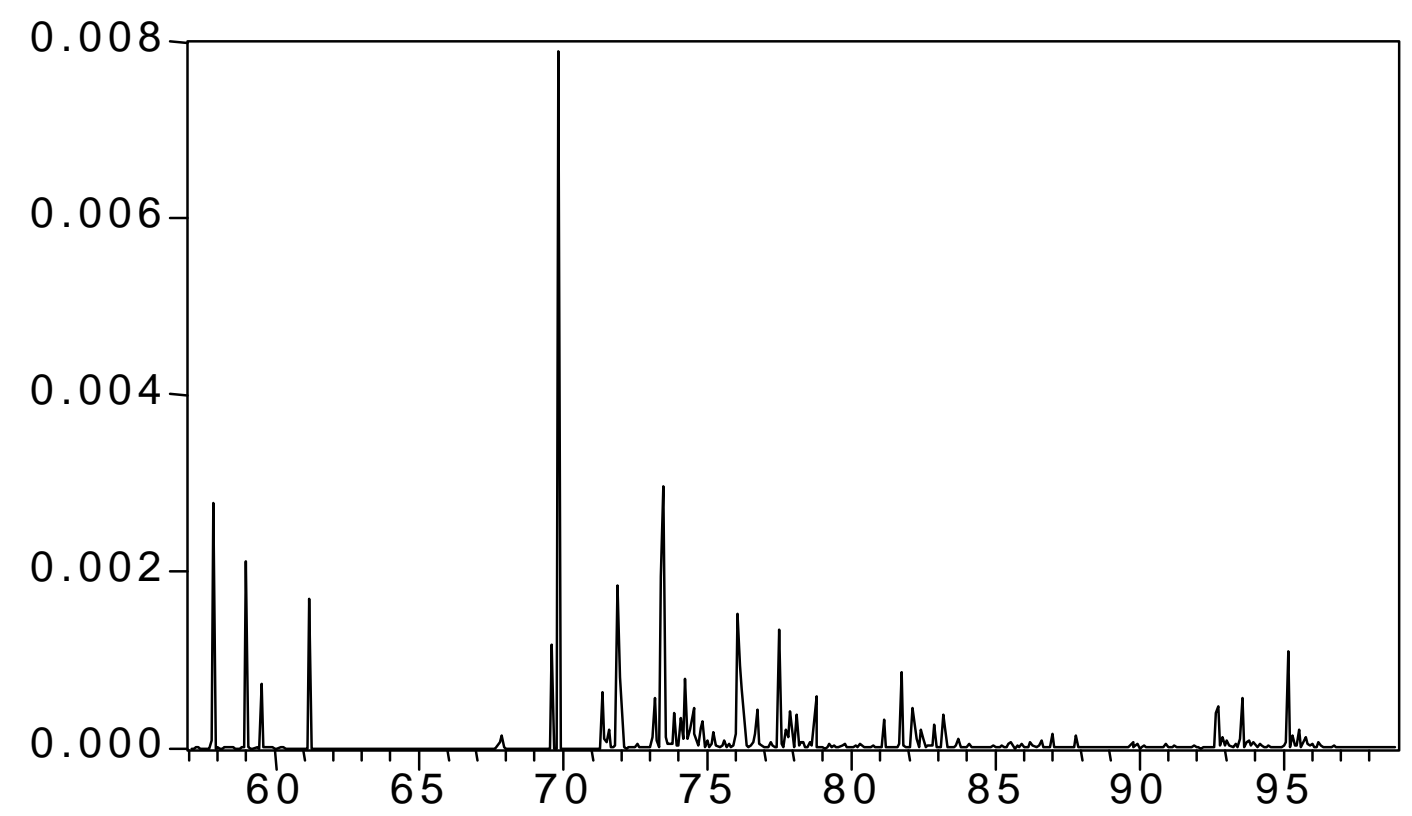




\section{Figure 4: Month-to-Month Percentage Changes in Real Commodity Prices (January 1957-December 1998)}
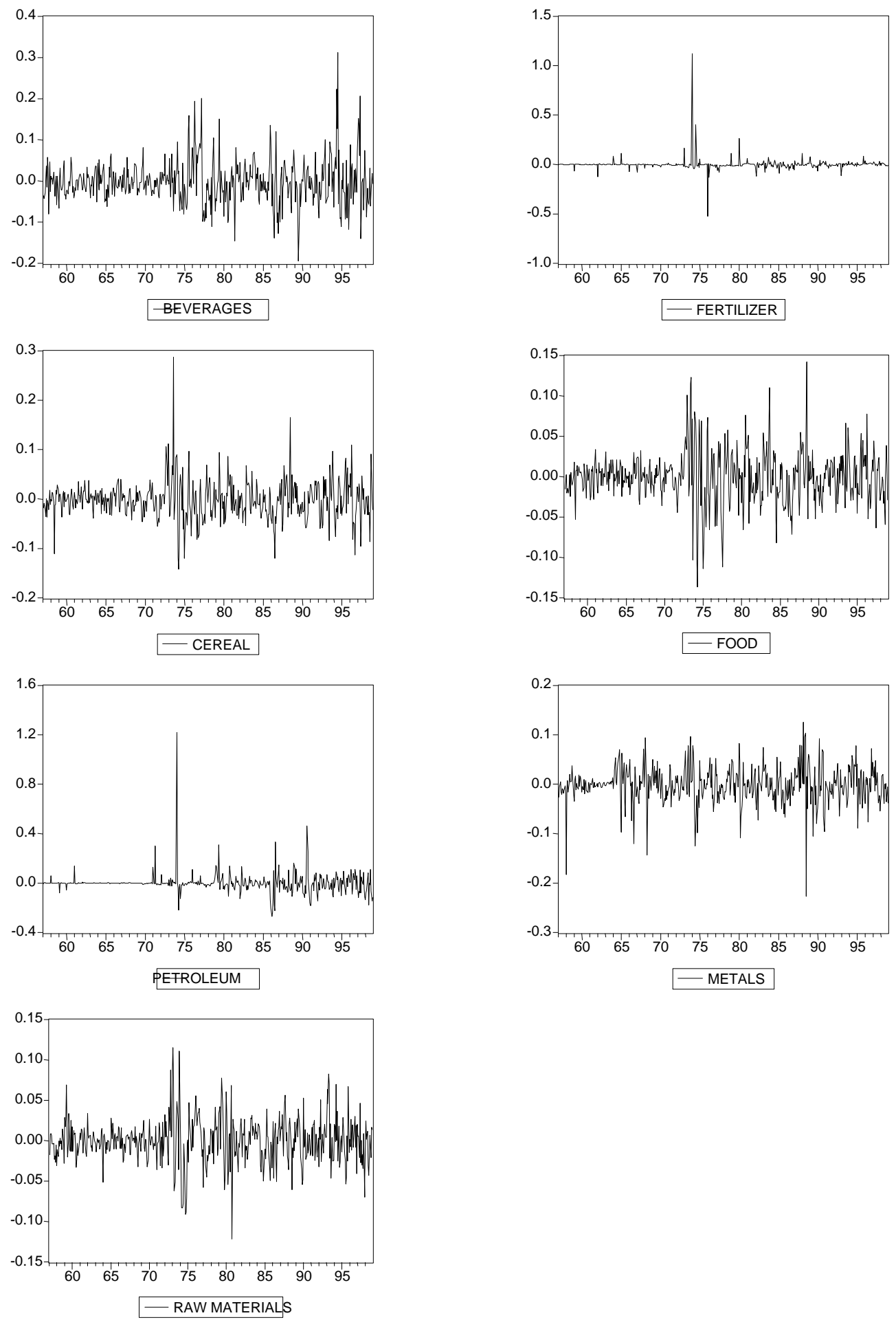
Figure 5

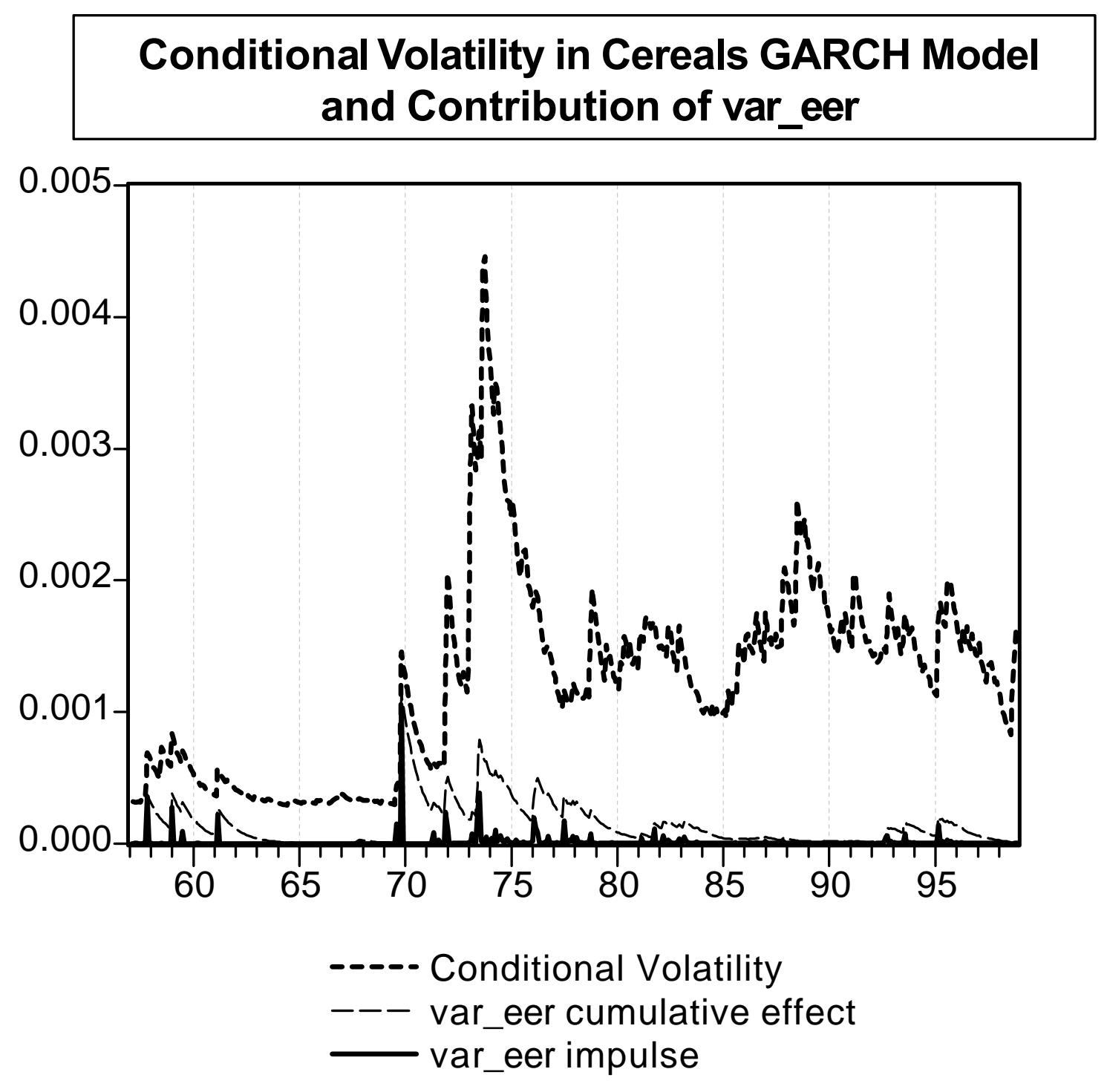


Figure 6

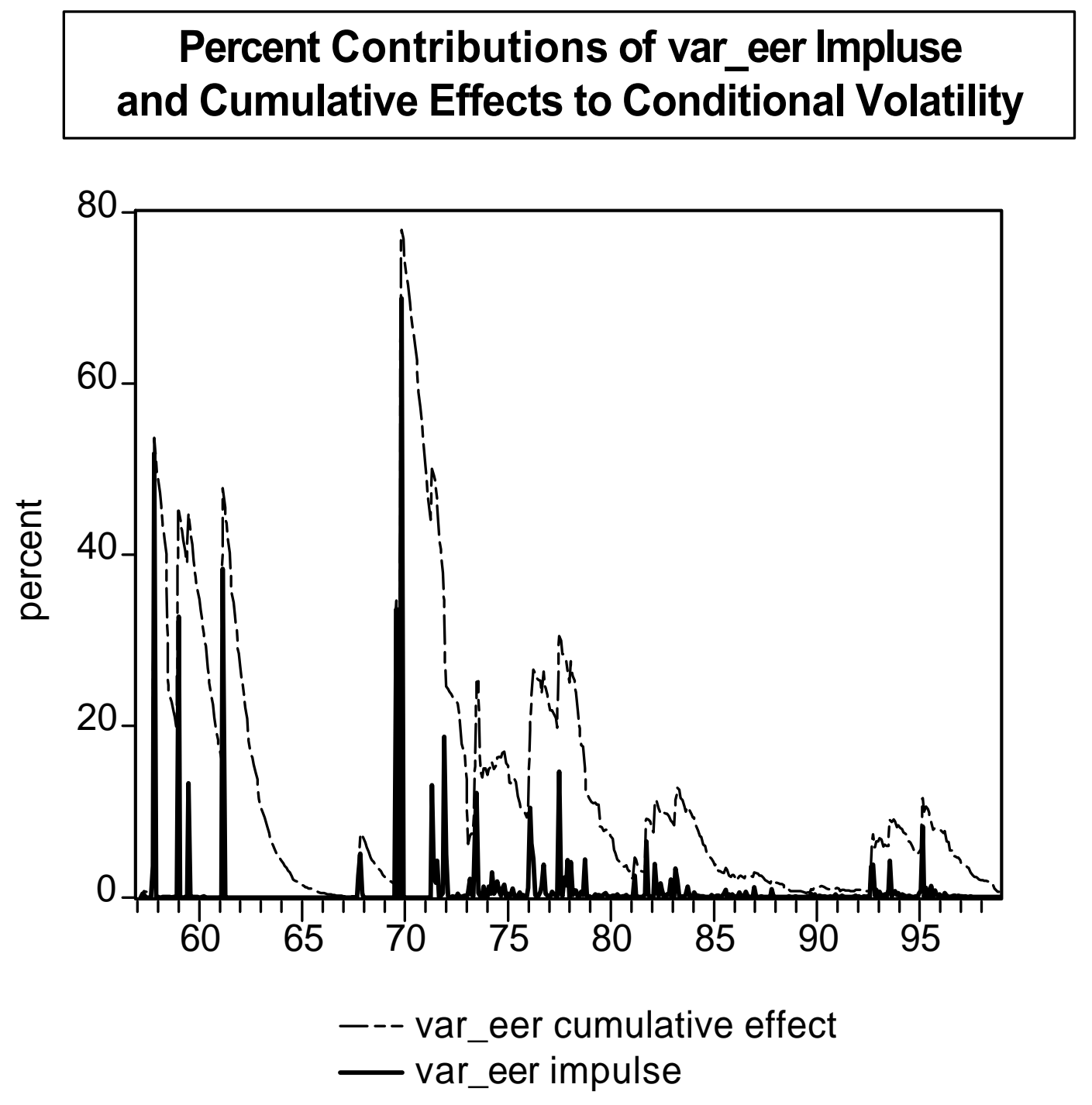




\section{$\underline{\text { References }}$}

Baxter, M. 1988. Business cycles, stylized facts, and the exchange rate regime: Evidence from the United States. Rochester Center for Economic Research Working Paper, No. 169.

Baxter, M. and A.C. Stockman, 1989, Business cycles and the exchange-rate regime: some international evidence, Journal of Monetary Economics 23, 377-400.

Beckerman, W. and T. Jenkinson, 1986, What stopped the inflation? unemployment or commodity prices? Economic Journal 96, 39-54.

Bollerslev, T. 1986, Generalized autoregressive conditional heteroskedasticity, Journal of Econometrics 31, 307-27.

Borensztein, E. and C. Reinhart. 1994. The macroeconomic determinants of commodity prices, IMF Staff Papers 41, 2 (June), 236-261.

Bui, N. and J. Pippenger. 1990, Commodity prices, exchange rates and their relative volatility, Journal of International Money and Finance, 9, 3-20.

Cashin, P., H. Liang, and J. McDermott. 1999, How persistent are shocks to world commodity prices? IMF Working Paper WP/99/80, forthcoming in IMF Staff Papers.

Cuddington, J.T. 1992, Long-run trends in 26 primary commodity prices: A disaggregated look at the Prebisch-Singer hypothesis, Journal of Development Economics 39, 207 227.

Cuddington, J.T. \& Liang, H. (1997). Commodity price volatility across exchange regimes. Georgetown Working Paper, \#97-17.

Cuddington, J.T. and C.M. Urzúa, 1989, Trend and cycles in the net barter terms of trade: A new approach, Economic Journal 99, 426-442.

De Grauwe, P. 1994. The Economics of Monetary Integration. $2^{\text {nd }}$ edition. New York: Oxford University Press.

Dinan, D. 1994. Ever Closer Union? (Lynne Rienner Publishers, Boulder, Colorado).

Dornbusch, R. 1985. Policy and performance links between LDC debtors and industrial nations, Brookings Papers on Economic Activity: 2, 303-356.

Enders, W. 1995, Applied econometric time series (New York, John Wiley \& Sons).

Engle, R.R. 1982, Autoregressive conditional heteroskedasticity with estimates of the variance of United Kingdom inflation, Econometrica 50, 987-1007.

Flood, R.R. and A.K. Rose, 1995, Exchange rates: A virtual quest for fundamentals, Journal of Monetary Economics 36, 3-37.

Frankel, J.A. (1986). Expectations and commodity price dynamics: The overshooting model. American Agricultural Economics, May, 344-348.

Gilbert, C.L. 1989. The impact of exchange rates and developing country debt on commodity prices, Economic Journal 99 (Sept.), 773-784.

Grilli, E.R. and M.C. Yang, 1988, Primary commodity prices, manufactured goods prices, and terms of trade of developing countries: What the long run shows, World Bank Economic Review 2, 1-48.

Hallwood, C.P. \& MacDonald, R. 1994. International money and finance. Oxford UK \& Cambridge USA: Blackwell Publishers.

Hamilton, J.D. 1983. Oil and the macroeconomy since World War II, The Journal of Political Economy, Vol. 91, No. 2. (Apr., 1983), pp. 228-248. 
Mussa, M. 1986, Nominal exchange rage regimes and the behavior of real exchange rates: Evidence and implications, Carnegie-Rochester Conference Series on Public Policy 25, 117-214.

Perron, P. 1990, Testing for a unit root in a time series with a changing mean, Journal of Business and Economic Statistics 8, 153-162.

Prebisch, R. 1950. The economic development of Latin America and its principal problems (United Nations, Lake Success).

Radetzki, Marian. 1990. A Guide to Primary Commodities in the World Economy, Cambridge, U.K.: Basil Blackwell Ltd. \{Need to check reference for accuracy, JTC\}

Reinhart, C.M. 1991. Fiscal policy, the real exchange rate, and commodity prices, IMF Staff Papers 38, 3(Sept.), 506-524.

Reinhart, C.M and P. Wickham, 1994, Commodity prices: Cyclical weakness or secular decline? IMF Staff Papers 41, 175-213.

Rogers, J.H. 1995, Real shocks and real exchange rates in really long-term data, International Finance Discussion Papers, Board of Governors of the Federal Reserve System. No. 493.

Singer, H. 1950, The distributions of gains between investing and borrowing countries, American Economic Review, Papers and Proceedings 40, 473-485.

Szasz, Andre. 1999. The Road to Monetary Union. St. Martins Press.

World Bank, 1994, Global economic prospects and the developing countries (Washington, DC.). 